Diunggah : Juli 2019

Diterima : Januari 2020

Dipublikasi : Januari 2020

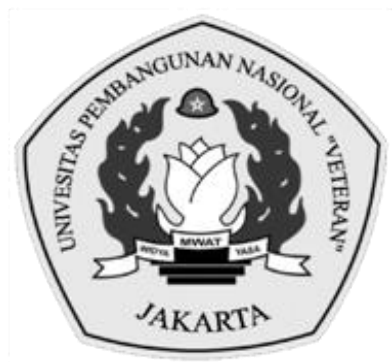

\title{
DETERMINAN PERILAKU KECURANGAN AKADEMIK DENGAN MENGGUNAKAN FRAUD DIAMOND DAN PERSPEKTIF DIRI MAHASISWA PENDIDIKAN AKUNTANSI
}

\author{
Ardiyanto Darma Tantama ${ }^{1}$, Isharijadi Isharijadi ${ }^{2}$, Elana Era ${ }^{3 *}$ \\ 19ardiyantotantama@gmail.com, 2isharijadi57@gmail.com, ${ }^{3}$ elaradita@gmail.com \\ 1, 2,3Universitas PGRI Madiun \\ *Penulis Korespondensi
}

\begin{abstract}
Abstrak
Penelitian ini bertujuan mengetahui apakah teori fraud diamond menjadi faktor yang mendorong terjadinya kecurangan di dalam akademik dan mengetahui penyebab lain yang memotivasi terjadinya perilaku curang dari sudut pandang mahasiswa. Metode yang digunakan kualitatif deskriptif. Teknik pengumpulan data menggunakan wawancara semi terbuka. Hasil penelitian ini menunjukkan faktor penyebab mahasiswa melakukan kecurangan karena adanya tekanan, kesempatan, rasionalisasi, dan kesempatan. Serta faktor lain dari mahasiswa melakukan kecurangan berasal dari dalam diri atau sudut pandang mahasiswa yaitu faktor kebiasaan, kepribadian, kepuasan, keinginan, kebutuhan, ketergantungan pada teman, dan faktor kurangnya percaya diri.
\end{abstract}

Kata Kunci: Kecurangan Akademik; Fraud Diamond; Perspektif Diri Mahasiswa

\begin{abstract}
This study aims to determine whether the theory of diamond fraud is a factor that encourages fraud in academics and to find out other causes that motivate fraudulent behavior from the point of view of student. Data obtained analyzed using qualitative descriptive methods. Data collection techniques using semi-open interviews and literature studies. The validity of the data is done by source triangulation. The results of this study indicate that the factors causing students to commit fraud are because of pressure, opportunity, rationalization, and capability. As well as other factors from students to make a lack of originating from within themselves or from the point of view of the students, namely factors of personality habits, desires, needs, reliance on friends and the factors of courage, self-confidence.
\end{abstract}

Keywords: Academic Fraud; Fraud Diamond; Students Prespective

\section{PENDAHULUAN}

Masih banyak terjadi kecurangan di dalam dunia pendidikan, diantaranya kecurangan yang terjadi saat waktu proses kegiatan belajar di kelas, pada saat ujian dan masih banyak lagi. Kecurangan tersebut biasanya terjadi dalam kegiatan Ujian Nasional maupun Ujian Sekolah (Susanti, 2017). Pendidikan seharusnya menjadi suatu fasilitas dan juga program bagi pendidik dan peserta didik demi menggapai suatu tujuan yang telah ditentukan berdasarkan undang-undang. Pendidikan juga 
berperan sebagai proses pembelajaran pengetahuan, ketrampilan, dan kebiasaan untuk menjadikan individu sebagai calon penerus generasi bangsa. Meningkatnya pendidikan menjadi penting dalam hal menjawab tantangan era globalisasi, kemajuan ilmu pengetahuan dan ilmu teknologi serta perpindahan yang terstruktur dari tenaga ahli. Pendidikan seharusnya bisa menghasilkan moral yang baik masyarakat.

Berkaitan dengan masalah kecurangan akademik yang dilakukan, banyak sekali alasan terbentuknya kecurangan akademik yang dilakukan segenap civitas akademika. Fraud diamond theory adalah teori pengembangan dari teori sebelumnya yaitu teori fraud triangle. Teori ini dikeluarkan tahun 2004 oleh Wolfe dan Hermanson. Terdapat proses lain untuk mencegah dan mendeteksi fraud dengan memperhitungkan faktor keempat selain peluang, tekanan, dan rasionalisasi, yaitu dengan memperhitungkan indikator kemampuan (capability) yang disebut sebagai fraud diamond (Priantara, 2013:47).

Penelitian mengenai teori fraud diamond sudah pernah dilakukan oleh beberapa ahli diantaranya riset yang digerakkan oleh Murdiansyah, Sudarma, \& Nurkholis (2017) mendapatkan hasil penelitian yang menunjukkan bahwa semua variabel yang berada dalam teori fraud diamond yaitu tekanan, kesempatan, rasionalisasi, dan kemampuan berpengaruh secara signifikan terhadap kegiatan curang di ranah akademik mahasiswa. Kemudian riset dari Hariri, Pradana, \& Rahman (2018) yang juga melakukan riset serupa dengan tema pendeteksian kecurangan dilihat dari sudut pandang fraud diamond. Riset dari Hariri, Pradana, dan Rahman (2018) menghasilkan bahwa keempat aspek yang ada di teori fraud diamond memiliki pengaruh pada perilaku kecurangan akademik mahasiswa. Selanjutnya, penelitian yang dilaksanakan oleh Yudiana \& Lastanti (2016) yang membahas analisis pengaruh fraud diamond terhadap kecurangan akademik mahasiswa. Hasil penelitian tersebut menjelaskan bahwa aspek tekanan tidak berpengaruh secara signifikan sedangkan peluang, rasionalisasi, dan kemampuan memiliki pengaruh signifikan pada kecurangan akademik mahasiswa.

Kemudian perbedaan penelitian yang sekarang dilakukan oleh peneliti dengan penelitian terdahulu ialah peneliti memutuskan untuk menggunakan metode kualitatif deskriptif, itu merupakan suatu perbedaan yang mencolok atau keunikan tersendiri bagi penelitian ini dikarenakan penelitian terdahulu yang ditemukan oleh peneliti rata-rata menggunakan metode kuantitaif dan mixed method. Sedangkan tujuan dilakukannya ialah untuk menguji apakah keempat elemen dari teori fraud diamond dijadikan sebagai faktor penyebab terjadinya perilaku menyimpang dalam bidang akademik yang dijalankan oleh peserta didik serta mengetahui penyebab faktor terjadinya kecurangan akademik dari sudut pandang mahasiswa.

\section{TINJAUAN PUSTAKA}

\section{Kecurangan Akademik}

Menurut pendapat Hartanto (2012) dapat dinyatakan bahwa perilaku kecurangan akademik bisa dibedakan beberapa bentuk yakni, perilaku curang saat mengerjakan tugas, kecurangan pada saat ujian, dan kecurangan dengan 
memberikan informasi yang salah (memanipulasi presensi). Berikut penjelasan dari ketiga indikator tersebut.

Pertama, tindakan kecurangan akademik pada waktu mengerjakan tugas yakni tindakan curang yang dilaksanakan peserta didik berupa menyontek jawaban teman, menyalin jawaban atau plagiat, memalsukan sumber, copy paste dari internet tanpa memasukkannya ke dalam sumber, dan melakukan beberapa cara agar tenggang waktu penumpukan tugas diperpanjang. Hal senada juga terdapat pada penelitian Nursalam, Bani, \& Munirah (2013) yang menemukan bahwa model kecurangan akademik adalah memplagiasi pekerjaan teman, melakukan copy paste, dan membuka internet saat ujian.

Kedua, tindakan kecurangan pada waktu UAS/UTS adalah tindakan kecurangan yang dilaksanakan peserta didik berupa memberikan informasi atau jawaban kepada teman, membawa catatan yang berisi materi yang sedang diujikan, bertanya kepada teman pada saat ujian berlangsung, melakukan plagiat terhadap jawaban teman, dan memberikan bocoran jawaban kepada teman kelas serta membantu teman untuk berbuat kecurangan. Hal diatas mendapat dukungan dalam riset yang digiatkan oleh Sagoro (2013) yang mengungkapkan kecurangan saat ujian meliputi mahasiswa membawa catatan kecil, mahasiswa bertanya pada teman, dan mahasiswa mencari bocoran soal.

Ketiga, kecurangan berupa memberikan informasi yang tidak benar. Dalam kaitan ini adalah kecurangan yang dilakukan tentang data kehadiran saat perkuliahan adalah kecurangan yang dilakukan dengan cara mengisi presensi yang fiktif artinya adalah jika seorang teman sekelasnya ada yang tidak mengikuti perkuliahan maka teman yang lain akan membantunya dengan cara mengisikan tulisan berupa tanda tangan pada nama teman yang tidak mengikuti perkuliahan, sehingga teman yang tidak mengikuti perkuliahan seakan-akan tetap dianggap mengikuti perkuliahan tersebut karena dengan batas presensi minimal 75\% adalah salah satu syarat sah untuk menjalani UAS/UTS. Hal ini dapat dibenarkan oleh penelitian yang dilakukan oleh Rafita (2012) yang menyebutkan bahwasannya terdapat kecurangan memalsukan presensi (titip absen) pada mahasiswa S1 Fakultas MIPA Universitas Islam Indonesia.

\section{Fraud Diamond}

Fraud diamond theory ialah teori pengembangan dari teori sebelumnya yaitu teori fraud triangle. Teori ini dikeluarkan tahun 2004 oleh Wolfe dan Hermanson. Terdapat proses lain untuk mencegah dan mendeteksi fraud dengan memperhitungkan faktor keempat selain peluang, tekanan, dan rasionalisasi, yaitu dengan memperhitungkan indikator kemampuan (capability) yang disebut sebagai fraud diamond (Priantara, 2013). Priantara (2013) menyebutkan keempat elemen dari fraud diamond adalah sebagai berikut. Tekanan (pressure), yaitu suatu dorongan atau kebutuhan yang dijadikan alasan untuk melakukan tindakan curang. Peluang (opportunity), yaitu adanya sistem yang lemah bisa dimanfaatkan untuk melakukan kecurangan. Rasionalisasi (rationalization), terjadi karena seseorang melakukan pembelaan terhadap tindakan kecurangannya. Kemampuan (capability), merupakan kecakapan yang dimiliki seseorang agar dapat melakukan tindakan 
kecurangan.

Di dalam Fraud diamond tersebut digambarkan bahwa keempat elemen saling berkaitan, akan tetapi kemampuan (capability) dianggap memilik kontribusi paling besar sebagai penyebab terjadinya perilaku curang. Hubungan antar elemen ada pada Gambar 1.

Gambar 1. Fraud Diamond

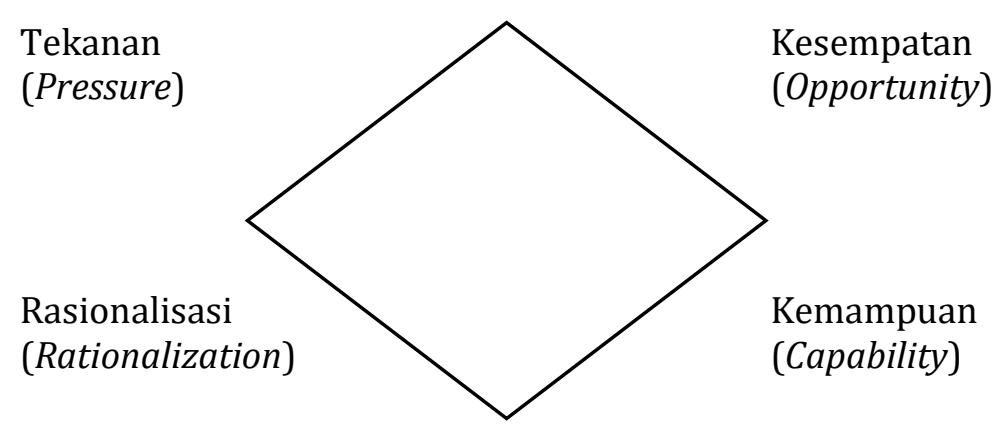

Sumber: Wolfe dan Hermanson (2014)

\section{METODOLOGI PENELITIAN}

Penelitian ini menggunakan metode penelitian kualitatif deskriptif. Teknik pengumpulan data menggunakan wawancara semi terstruktur (semi terbuka). Wawancara tersebut meliputi pertanyaan-pertanyaan mengenai 4 faktor terjadinya kecurangan dilihat dari fraud diamond theory yakni tekanan, peluang, rasionalisasi, dan kemampuan serta sudut pandang dari mahasiswa Program studi Pendidikan Akuntansi Universitas PGRI Madiun. Wawancara disini dilakukan secara semi terbuka artinya bahwa pertanyaan yang diberikan ada yang tertutup dan ada yang terbuka atau bebas. Maksud dari tertutup ialah pertanyaan yang terfokus dari keempat elemen dari fraud diamond. Sedangkan terbuka maksudnya adalah pertanyaan yang bebas tetapi tetap dalam satu bahasan karena di sini membahas mengenai sudut pandang mahasiswa itu sendiri mengenai kecurangan akademik, agar memungkinkan peneliti menemukan faktor lain di luar kerangka teori.

Sumber data yang digunakan yaitu sumber data primer, dengan mengambil data dari mahasiswa program studi pendidikan akuntansi Universitas PGRI Madiun dan peneliti mengambil data untuk penelitian ini dimulai pada bulan April hingga Mei sebanyak 8 informan utama yakni mahasiswa dari masing-masing perwakilan kelas yang ada di prodi pendidikan akuntansi serta informan penguat sejumlah 27 informan meliputi 8 orang tua dari informan utama, 8 sahabat di dalam kelas dari informan utama, 8 sahabat luar kampus dari informan utama, dan 3 dosen pengajar. Informan tersebut dipergunakan demi mendukukung pernyataan dari 8 informan utama diatas apakah jawabannya bisa dipercaya atau tidak. Teknik analisis data dengan tahapan reduksi data, penyajian data, dan menarik kesimpulan. Teknik keabsahan data menggunakan triangulasi sumber pada jawaban yang dikeluarkan oleh 8 informan utama dan 27 informan penguat serta bentuk dari triangulasi sumber tersebut ialah triangulasi sumber secara deskripsi. 


\section{HASIL DAN PEMBAHASAN}

Berdasarkan hasil wawancara, penjabaran hasil penelitian sesuai dengan masing-masing indikator sebagai berikut:

\section{Kecurangan Akademik}

Informan 1, 2, 3, 4, 5, 6, 7, dan 8 mengatakan bahwa pernah dan sering melakukan kecurangan berupa tindakan menyimpang di dalam kelas pada saat ujian, mengerjakan tugas, dan pada saat mengisi presensi perkuliahan itu contohnya dengan titip kepada teman untuk mengisi daftar hadir dan juga menerima titipan dari teman yang tidak masuk kuliah untuk mengisi daftar hadir.

Kecurangan dari mahasiswa pada saat UTS/UAS tersebut meliputi bertanya kepada rekan yang paling dekat untuk meminta jawaban dan melakukan rencana atau kerjasama yang baik untuk melakukan kecurangan. Kemudian untuk kecurangan pada saat mengerjakan tugas diantaranya seperti menyontek pekerjaan teman, melakukan pemalsuan sumber jawaban, melakukan copy paste dari internet, dan melakukan plagiat terhadap jawaban teman. Selanjutnya, mengenai kecurangan mahasiswa mengisi data presensi yang fiktif dimaksudkan adalah mahasiswa melakukan titip untuk mengisi data absen kepada teman sekelas atau menerima titipan dari teman untuk mengisi data absen jika teman tersebut tidak mengikuti perkuliahan. Hal tersebut seperti yang diutarakan oleh informan 3 sebagai berikut.

"Tentu saja pernah, ya kecurangannya itu seperti bertanya pada teman saat ujian, menyontek tugas teman dan juga terkadang titip absen dan itu saya lakukan memang dengan sengaja."

Berdasarkan pernyataan dari kedelapan informan tersebut bisa dipercayai dan dipertangungjawabkan dengan pembuktian bahwa dosen, sahabat atau teman dekat dari kedelapan informan tersebut mengatakan bahwasannya mereka benarbenar melakukan kecurangan di dalam kelas. Berdasarkan hasil wawancara yang telah dilakukan oleh peneliti terhadap informan dan teman dekat informan (validitas sumber) dapat disimpulkan bahwa kedelapan informan tersebut memenuhi untuk dijadikan sebagai informan karena jawaban dan pernyataannya dapat dipertanggungjawabkan.

Hasil penelitian ini di dukung dengan riset yang dilaksanakan oleh Nursalam, Bani, \& Munirah (2013); Rafita (2012) tentang bentuk tindakan curang yang dilakukan oleh mahasiswa. Bentuknya meliputi menyontek tugas teman, bertanya dan membawa catatan pada saat ujian, memplagiasi tugas teman serta mengenai memanipulasi presensi (titip absen atau nitip absen).

\section{Fraud Diamond}

\section{Tekanan}

Keuangan. Keuangan menjadi salah satu aspek yang masuk dalam indikator tekanan, tekanan keuangan disini dimaksudkan sebagai tekanan mengenai beban pembayaran seluruh perkuliahan. Berdasarkan jawaban dari seluruh informan utama dan informan pendukung dapat diambil kesimpulan bahwasannya hasil penelitian ini menuturkan salah satu faktor penyebab terjadinya kecurangan yang dilakukan oleh mahasiswa di kelas adalah faktor tekanan finansial atau keuangan. 
Seperti yang secara eksplisit disampaikan oleh informan kedua yang takut mengulang mata kuliah.

"Tentunya iya, karena agar nanti kedepannya tidak mengalami penambahan pembayaran seperti perbaikan lulus dan semester pendek."

Hal ini sesuai dengan pernyataan dari Dewi (2017) dan Karyono (2013) yang mengatakan bahwa salah satu faktor kecurangan akademik dalam ranah tekanan adalah tekanan keuangan atau biasa disebut dengan tekanan finansial.

Kebiasaan individu. Kebiasaan dari individu ini merupakan salah satu aspek yang masuk di dalam indikator tekanan, dikarenakan faktor kebiasaan terkait dengan faktor pemicu kecurangan. Yang dimaksud dengan kebiasaan individu ialah kegiatan yang sering dilakukan mahasiswa setelah perkuliahan selesai. Dari proses wawancara yang dilakukan peneliti, keseluruhan jawaban yang di dapatkan peneliti dari informan mengerucut pada satu titik yaitu faktor kebiasaan setelah perkuliahan merupakan salah satu faktor yang menjadi penyebab untuk dilakukannya kecurangan akademik di kelas karena mahasiswa tidak menggunakan waktu setelah perkuliahan dengan baik, seperti yang dinyatakan oleh informan ketiga.

"Seringnya sehabis kuliah saya nongkrong bersama teman-teman dan saya tidak memanfaatkan untuk belajar ataupun nugas, ya akhirnya dengan meminta jawaban pada teman adalah cara saya untuk memenuhi tugas dari dosen."

Hal ini didukung dan sesuai dengan pernyataan dari Friyatmi (2011) yang menyebutkan bahwa faktor kecurangan berasal dari faktor internal yaitu konsep diri dan motivasi individu. Konsep diri ini dapat dikatakan sebagai kebiasaan karena dibawa sejak kecil kemudian secara bertahap akan mengalami perubahan dan perkembangan individu.

Lingkungan. Aspek lingkungan juga termasuk ke dalam faktor pemicu kecurangan yang berada di dalam indikator tekanan. Dari hasil wawancara yang dilakukan peneliti dapat diputuskan bahwa bagaimana pun lingkungan yang mahasiswa alami dapat menjadi faktor untuk melakukan kecurangan. Hal ini termasuk hal yang unik dan peneliti menemukan sesuatu yang baru dalam penelitian ini yaitu lingkungan yang berbeda-beda yang dialami oleh mahasiswa tersebut tetap menjadi faktor untuk melakukan kecurangan karena dari masingmsing mahasiswa memiliki cara atau kepribadian sendiri-sendiri untuk menanggapi. Misalnya informan pertama yang merasa lingkungan nyaman adalah faktor penyebab curang.

“...Menurut saya lingkungan yang nyaman malah menjadi alasan saya untuk melakukan kecurangan karena teman sekelas mudah diajak kerjasama."

Hal sebaliknya diungkapkan oleh informan kedelapan sebagai berikut.

"Kurang nyaman. Dan untuk penilaian dosen itu kurang objektif serta suasana tersebut condong untuk melakukan kecurangan."

Hasil penelitian ini senada dan sesuai dengan penelitian yang dilaksanakan oleh Murdiansyah et al., (2017) menyatakan bahwa tuntutan lingkungan juga 
sebagai salah faktor penyebab munculnya tindakan kecurangan.

Tuntutan Keluarga. Hal ini dimaksudkan bahwa tuntutan keluarga ialah tekanan yang dihadirkan oleh keluarga (orang tua atau orang terdekat). Sesuai hasil wawancara yang dilakukan oleh peneliti dapat ditarik garis besar bahwa hal ini merupakan temuan yang bisa dikatakan unik dikarenakan adanya tuntutan dan tidak adanya tuntutan keluarga tetap menjadi faktor untuk curang tetapi dalam konteks yang berbeda, jika adanya tuntutan dari keluarga untuk berprestasi hal tersebut membuat mahasiswa merasa ditekan dan tidak adanya rasa percaya diri yang kuat dari mahasiswa terhadap kemampuan ilmiahnya sendiri sehingga selalu menghalalkan segala cara untuk bisa dikatakan berprestasi. Misalnya yang diungkapkan informan kedua yang tidak mendapat tekanan keluarga.

"Selama ini tidak ada tuntutan dari keluarga tapi saya disini ingin berpretasi dan untuk mencapainya itu saya melakukan kecurangan."

Sedangkan anak yang mendapat tuntutan keluarga dialami oleh informan ketiga yang memberi pengakuan sebagai berikut.

"Ya ada tuntutan untuk berprestasi dan lulus dengan cepat dan untuk memenuhi tuntutan saya menghalalkan segara cara untuk mendapatkan hasil yang baik"

Hal ini senada dengan penelitian terdahulu serta mendapatkan dukungan dari penelitian yang dilakukan oleh Murdiansyah et al., (2017) mengungkapkan tuntutan keluarga juga merupakan faktor untuk melakukan tindak kecurangan. Sedangkan dengan tidak adanya tuntutan ini membuat perasaan mahasiswa tidak diperhatikan oleh orang tua sehingga mahasiswa lebih bebas untuk melakukan kecurangan, ini bisa dikatakan temuan yang baru karena meskipun tidak adanya tuntutan dari keluarga tetap menjadi faktor untuk curang karena individu merasa tidak diperhatikan oleh orang tua.

\section{Kesempatan}

Lemahnya pengendalian dan pemeriksaan. Aspek lemahnya pengendalian dan pemeriksaan ini termasuk ke dalam salah satu aspek yang ada indikator kesempatan. Proses wawancara yang dilakukan oleh peneliti menunjukkan bahwa mengenai lemahnya pengendalian dan pemeriksaan yang dilakukan oleh pendidik atau dosen kepada mahasiswa menjadi faktor untuk bertindak curang. Kelemahan tersebut tidak di sia-siakan oleh mahasiswa untuk melakukan kecurangan karena mahasiswa merasa diberi ruang yang lebih untuk melakukan kecurangan di kelas. Misalnya yang diungkapkan informan keenam.

"Selama ini belum pernah ketahuan ya karena menurut saya dosennya kurang dalam pengawasan."

Hal ini didukung dengan pernyataan dari Murdiansyah et al., (2017) yang menyatakan bahwasannya kesempatan melakukan kecurangan hadir ketika terdapat kelemahan dalam sebuah kebijakan atau sistem yang dijalankan oleh dosen.

Kualitas pekerjaan dan sikap apatis. Aspek ini juga termasuk ke dalam salah 
satu indikator kesempatan. Hal ini bisa dikatakan berkaitan langsung antara mahasiswa dan dosen. Kesimpulan yang diperoleh dari wawancara yang dilaksanakan peneliti adalah bahwa dalam penilaian yang diberikan oleh dosen dan sikap apatis atau kurang perhatian dari dosen membuat mahasiswa untuk melakukan kecurangan di kelas. Berikut pengakuan informan kelima.

\footnotetext{
"Menurut saya, penilaian dosen tidak bisa dikatakan objektif karena tidak ada transparansi nilai antar dosen dan mahasiswa serta dosen terkesan bersikap apatis terhadap mahasiswa, sehingga itu membuat saya untuk curang."
}

Perihal tersebut dapat dipercayai karena dari keseluruhan informan menyebutkan hal yang sama dan juga dari kedelapan validitas sumber (narasumber) menuturkan hal yang sama. Dosen pengajar juga mengatakan bahwa penilaian masih kurang obyektif karena sulit untuk menerima nilai yang murni banyak sekali tambahan nilai yang diberikan untuk mahasiswa serta dosen masih ada yang kurang perhatian kepada mahasiswa. Sekalipun ada dosen yang perhatian itu pun tidak mendetail memahaminya seperti layaknya keluarga memahami anaknya. Hasil ini sejalan dengan hasil penelitian oleh Sagoro (2013) yang menyebutkan bahwa mahasiswa melakukan kecurangan salah satunya karena tidak pahamnya dosen terkait dengan tugasnya, hanya sedikit dosen yang mengerti bahwa kepedulian dari dosen sangat berharga untuk mahasiswa sehingga mahasiswa berasumsi bahwa tidak pedulinya dosen adalah kesempatan untuk curang.

Gagal Mendisiplinkan. Aspek ini berkaitan dengan peraturan yang telah dicanangkan oleh dosen kepada mahasiswa. Proses wawancara menghasilkan jawaban yang relevan antara informan 1 sampai 8 yakni aspek gagal mendisiplinkan ini adalah sebagai faktor penyebab mahasiswa untuk melakukan kecurangan. Dalam kaitan ini, dikarenakan dosen tidak tegas dalam memberikan hukuman dan tidak ada komitmen yang profesional dari dosen dalam pemberian sanksi dan hukuman kepada mahasiswa yang ketahuan melakukan kecurangan. Informan kelima kembali memberikan pengakuan mengejutkan.

\footnotetext{
"Selama ini saya tidak pernah mendapat sanksi sehingga saya terus mengulangi perbuatan yang saya lakukan."
}

Hasil penelitian ini sesuai dengan penelitian yang dilakukan Murdiansyah et al., (2017) mengungkapkan bahwa penerapan sanksi yang tidak tegas dan tidak adanya pengambilan tindakan secara tegas oleh pengawas/dosen akan membuka kesempatan bagi mahasiswa untuk melakukan kecurangan.

Kurangnya akses informasi. Kurangnya akses informasi ini dimaksudkan bahwa dosen kurang mengenal atau memahami karakter dan sifat setiap mahasiswa. Setalah dilakukannya wawancara kepada dosen dan mahasiswa bisa ditarik kesimpulan bahwa aspek kurangnya akses informasi dari dosen kepada mahasiswa merupakan salah satu faktor penyebab mahasiswa untuk melakukan kecurangan akademik di kelas. Mahasiswa beranggapan bahwa dosen terkesan cuek terhadap sikap dan perilaku dari setiap mahasiswa sehingga mahasiswa merasa tidak diperhatikan dan juga digunakan alasan dan penyebab untuk melakukan kecurangan. 
"Tidak selalu (mengenal karakter) sih, dari sini saya beranggapan bahwa dosen tidak banyak mengenal mahasiswa dan itu saya jadikan juga sebagai kesempatan saya untuk curang."

Pernyataan diatas sesuai dan mendapatkan dukungan dari pernyataan yang diungkapkan oleh Sagoro (2013) bahwa hanya sedikit dosen yang mengetahui apa yang dilakukan oleh mahasiswa secara detail baik di kelas maupun di luar kelas sehingga mahasiswa akan melakukan kecurangan.

\section{Rasionalisasi}

Melakukan Pembenaran. Pembenaran ini dimaksudkan bahwa mahasiswa memiliki argumen bahwasannya apa yang dilakukannya tersebut bukan merupakan sebuah kecurangan. Setelah dilakukan wawancara kepada mahasiswa oleh peneliti dapat disimpulkan bahwa ada dua jawaban yang berasal dari mahasiswa menyebutkan bahwa melakukan kecurangan didasari dengan anggapan karena orang lain melakukan hal yang sama. Misalnya yang diungkapkan informan ketujuh.

\footnotetext{
"Iya saya melakukan pembenaran dengan cara bahwa orang lain juga melakukan hal yang sama seperti saya."
}

Sedangkan sisanya yaitu informan 4, 5, dan 8 tidak melakukan pembenaran jika ketahuan melakukan kecurangan lebih terkesan pasrah dan bertanggung jawab dengan apa yang dilakukannya. Informan keempat mengungkapkannya secara gambling.

"Kalo saya malah mengakui apa yang saya lakukan dan bertanggung jawab."

Hal ini merupakan temuan yang terbilang baru dan unik, mahasiswa tidak melakukan pembenaran karena atas dasar ingin bertanggung jawab terhadap apa yang dilakukannya karena untuk melindungi teman yang lain yang melakukan kecurangan. Pernyataan dari informan tersebut sesuai dengan penelitian yang dilakukan oleh Mufakkir \& Listiadi (2016) yang menyebutkan bahwa anggapan melakukan kecurangan karena atas dasar orang lain juga melakukannya.

Merasa mempunyai pengaruh atau jasa. Perihal ini disebutkan bahwasannya seorang mahasiswa merasa berjasa atau pernah memberikan bantuan secara besar terhadap suatu organisasi. Proses wawancara yang dilakukan peneliti dapat diberi simpulan bahwa ada dua jawaban yang dihasilkan dari proses wawancara yaitu yang pertama informan $1,4,5,6,7$, dan 8 mengatakan tidak merasa mempunyai pengaruh yang besar. Akan tetapi untuk melakukan kecurangan mereka menggunakan kerjasama antar mahasiswa dengan didasari oleh kebersamaan, seperti yang dikatakan informan keempat.

"Saya tidak merasa seperti itu (memiliki pengaruh yang besar), karena di kelas saya mengedepankan kebersamaan."

Pendapatan kedua, yaitu dari informan 2 dan 3, menyebutkan bahwa mereka mempunyai pengaruh besar di kelas dan menggunakannya untuk melakukan kecurangan serta mereka beranggapan bahwa pengaruhnya tersebut untuk 
memudahkannya untuk melakukan perilaku curang.

"Ya saya merasa bahwa saya mempunyai pengaruh karena saya adalah mantan ketua kelas, sehingga saya dengan mudah untuk meminta jawaban dan menyontek."

Jadi, kesimpulannya adalah meskipun mahasiswa mempunyai pengaruh atau tidak di kelas tetap menjadi faktor kecurangan untuk melakukan kecurangan hanya saja perbedaan terletak pada alasan yang dialami oleh masing-masing pihak. Hal inii dapat didukung dengan hasil survey dan penelitian yang dilakukan oleh Widianto \& Sari (2017) menemukan peristiwa pada saat ujian yaitu menyalin jawaban dari mahasiswa yang duduk berdekatan dan kerjasama antar mahasiswa yang dilakukan 2 orang atau lebih yang sudah direncanakan jauh-jauh hari.

\section{Kemampuan}

Kemampuan merupakan faktor penyebab kecurangan yang sangat penting dikarenakan mahasiswa harus memiliki kemampuan untuk melakukan suatu kecurangan. Menurut hasil wawancara, kemampuan ini adalah kemampuan untuk menganalisis dan melihat kelemahan yang ada pada sistem yang dijalankan oleh dosen atau pada kepribadian dosen dan kelemahan tersebut digunakan untuk bertindak curang, seperti yang diutarakan oleh informan ketujuh.

"Iya mas, saya bisa melihat kelemahan seperti itu dan itu saya gunakan sebaik mungkin untuk melakukan kecurangan."

Hasil penelitian ini sesuai dengan riset yang dilakukan oleh Yudiana \& Lastanti (2016) yang mengungkapkan bahwa mahasiswa mempunyai kemampuan dalam ranah akademik dan kemampuan merupakan faktor yang mempengaruhi untuk melakukan kecurangan akademik. Ini juga sesuai dengan penelitian Artani \& Wetra (2017) menyatakan bahwasannya kemampuan merupakan faktor penting yang mempengaruhi mahasiswa untuk melakukan kecurangan.

\section{Perspektif atau Sudut Pandang Mahasiswa}

Faktor lain di luar fraud diamond untuk melakukan kecurangan, penelitian ini menghasilkan bahwa terdapat faktor lain dari sudut pandang mahasiswa yaitu faktor yang dirasakan sendiri oleh mahasiswa antara lain, faktor keinginan, faktor kebutuhan, faktor kebiasaan, faktor kepribadian, faktor kepuasaan, faktor kurangnya percaya diri, dan faktor ketergantungan terhadap teman. Hal ini didukung oleh pernyataan salah satu informan yakni,

"Ada, faktor kebutuhan akan jawaban, faktor kebiasaan atau kepribadian dari dulu sering curang dan juga faktor kepuasan itu yang saya rasakan."

Kepuasan yang dimaksudkan adalah kepuasan dalam mengerjakan tugas dengan cara menyontek ke mahasiswa lain dan tidak puas jika mengerjakan sendiri. Ketidakpuasan itu disebabkan karena kurangnya percaya diri dan ketergantungan terhadap teman. Budaya mengerjakan secara bersama-sama rupanya malah mengarahkan anak untuk tidak mandiri. 


\section{SIMPULAN}

Kecurangan akademik yang sering dilakukan oleh mahasiswa adalah menyontek pekerjaan teman untuk memenuhi tugas yang diberikan oleh dosen, bertanya pada teman dan membawa catatan kecil pada saat ujian, dan memanipulasi presensi saat perkuliahan berlangsung dengan cara menitip kepada teman untuk mengisi daftar hadir ketika tidak mengikuti perkuliahan dan menerima titipan dari teman untuk mengisi daftar hadir perkuliahan ketika teman tidak mengikuti perkuliahan. Secara komprehensif bahwa dari keempat elemen yang ada dalam teori fraud diamond yaitu tekanan, kesempatan, rasionalisasi, dan kemampuan menjadi faktor mahasiswa program studi pendidikan akuntansi untuk melakukan kecurangan akademik di dalam kelas. Terdapat faktor-faktor lain yang hadir dari dalam diri mahasiswa program studi pendidikan akuntansi di luar dari teori fraud diamond yaitu faktor kebutuhan akan jawaban, faktor keinginan untuk mendapatkan nilai yang baik dan maksimal, faktor kepuasan yang jika mengerjakan sendiri tidak puas dan akan puas jika menyontek atau bertanya pada teman, faktor kebiasaan menyontek dan kepribadian yang sudah terbawa sejak masih bersekolah, faktor ketergantungan teman akan selalu meminta dan menunggu jawaban dari teman dan faktor kurangnya percaya diri dari mahasiswa untuk mengerjakan dan menyelesaikan tugas sendiri dan kurangnya percaya diri terhadap kemampuan mahasiswa itu sendiri.

\section{Keterbatasan}

Penelitian ini memiliki keterbatasan dari cara peneliti memperoleh data yaitu peneliti hanya sekali dapat melakukan observasi dan wawancara ke lingkungan rumah informan karena jarak tempuhnya cukup jauh dan waktu penelitian yang tersedia cukup singkat. Namun, hasil ini sudah cukup membuktikan bahwa teori fraud diamond masih belum cukup menjelaskan faktor-faktor kecurangan.

\section{Saran}

Untuk penelitian selanjutnya diharapkan kepada peneliti untuk lebih mendalami informan dan seluruh elemen yang terkait dengan tema atau bahasan yang diambil dalam penelitian selanjutnya. Dosen diharapkan memiliki komitmen yang tinggi untuk berpartisipasi turut hadir dalam mengurangi dan mencegah kecurangan yang dilakukan oleh mahasiswa.

\section{DAFTAR PUSTAKA}

Artani. K.T.B, \& Wetra. I.W. (2017). Pengaruh Academic Self Efficacy Dan Fraud Diamond Terhadap Perilaku Kecurangan Akademik Mahasiswa Akuntansi Di Bali. Jurnal Riset Akuntansi (JUARA), 7(2), 123-132.

Dewi, R. (2017). Fraud Penyebab Dan Pencegahnya. Bandung: CV. Alfabeta.

Friyatmi. (2011). Faktor-faktor Penentu Perilaku Mencontek di Kalangan 
Mahasiswa Fakultas Ekonomi UNP. Tingkap, 7(2), 173-188.

Hariri, Pradana, A.W., \& Rahman, F. (2018). Mendeteksi Perilaku Kecurangan Akademik dengan Perspektif Fraud Diamond Theory. Jurnal Ketahanan Pangan, 2(1), 1-11.

Hartanto, D. (2012). Bimbingan \& konseling menyontek: mengungkap akar masalah dan solusinya. Jakarta: Indeks.

Karyono. (2013). Forensik Fraud. Yogyakarta: Penerbit Andi.

Mufakkir, M.E., \& Listiadi, A. (2016). Pengaruh Faktor Yang Terdapat Dalam Dimensi Fraud Triangle Terhadap Perilaku Kecurangan Akademik. Jurnal Pendidikan Akuntansi (JPAK), 0(0), 1-9.

Murdiansyah, I., Sudarma, M., \& Nurkholis. (2017). Pengaruh Dimensi Fraud Diamond Terhadap Perilaku Kecurangan Akademik. Jurnal Akuntansi Aktual, $4(2), 121-133$.

Nursalam, Bani, S., \& Munirah. (2013). Bentuk Kecurangan Akademik (Academic Cheating) Mahasiswa PGMI Fakultas Tarbiyah Dan Keguruan UIN Alauddin Makassar. Jurnal Lentera Pendidikan, 16(36), 127-138.

Priantara, D. (2013). Fraud Auditing \& Investigation. Jakarta: Mitra Wacana Media.

Rafita, Y. (2012). Analisis Faktor-Faktor Yang Mempengaruhi Mahasiswa S1 Fakultas Matematika Dan Ilmu, 5, 25-37.

Sagoro, M.E. (2013). Pensinergian Mahasiswa, Dosen, Dan Lembaga Dalam Pencegahan Kecurangan Akademik Mahasiswa Akuntansi, XI(2), 54-67.

Susanti, A. (2017). Pendidikan Belum Berhasil Ciptakan Moral Baik. Retrieved March 31, 2019, from https://news.okezone.com/read/2017/01/11/65/1588492/pendidikanbelum-berhasil-ciptakan-moral-baik

Widianto, A., \& Sari, Y. (2017). Deteksi Kecurangan Akademik Pada Mahasiswa D III Akuntansi Politeknik Harapan Bersama Tegal Dengan Model Fraud Triangle. Jurnal AKSI (Akuntansi Dan Sistem Informasi), 1(2007), 29-37.

Yudiana, A., \& Lastanti, H. (2016). Analisis Pengaruh Dimensi Fraud Diamond Terhadap Perilaku Kecurangan Akademik Mahasiswa Fakultas Ekonomi. Seminar Nasional Dan Call Paper Fakultas Ekonomi UNIBA Surakarta, (September), 412-422. 